International Journal of Arts and Humanities Studies (IJAHS)

ISSN: $2754-4311$

DOI: 10.32996/ijahs

Journal Homepage: www.al-kindipublisher.com/index.php/ijahs

\title{
Linguistic Intervention in Making Fiscal and Monetary Policy
}

\author{
Iskandarsyah Siregar ${ }^{1} \square$ Firlii Rahmadiyah $^{2}$ and Alisha Firiska Qatrunnada Siregar ${ }^{3}$ \\ ${ }^{123}$ Universitas Nasional, Jakarta, Indonesia; Regaranggi Institute, Indonesia \\ $\square$ Corresponding Author: Iskandarsyah Siregar, E-mail: regaranggi@presidency.com, https://orcid.org/0000-0002-4529- \\ 6525
}

ARTICLE INFO

Received: 08 October 2021

Accepted: 02 November 2021

Published: 11 November 2021

DOI: 10.32996/ijahs.2021.1.1.8

\section{KEYWORDS}

Linguistics, critical discourse

analysis, policy, fiscal, monetary

\section{ABSTRACT}

Linguistics is a branch of science that can maneuver to solve various problems. Linguistics began to succeed in canceling the predicate given to laypeople, namely as a linguistic science. Linguistics can even be a solution for various other disciplines, including fiscal and monetary policy issues. Fiscal and monetary policies that require analysis of the past, present, and future phenomena can be answered immediately with a linguistic analysis knife. Critical discourse analysis is confidently taking action as a solution to this problem. The holistic interpretative approach used in this study tries to analyze the text by relating and relevant to the context and then abstracting it into a complete picture. This study succeeded in finding that critical discourse analysis can play a role in 3 things related to fiscal and monetary policy, namely: (1) text analysis is an analysis of linguistic elements in sentence construction used in formulating policies, (2) analysis of discourse practice is a background analysis behind the decision-makers who formulate policies and other situations and conditions behind the birth of business economic policies, and (3) analysis of socio-cultural and political is an analysis that is identifying the changes that occur as a result of these policies. This proves the effectiveness of Linguistics in studying fiscal and monetary policy issues.

\section{Introduction}

Various problems have been present in human civilization since the early creation of this world. Indeed, it will continue until the end of time. Consciously or not, each of these problems is interrelated. There is no single problem that stands alone and can be solved with only one discipline. Relevant to this, a discipline is not only limited to being a solution to one problem domain. That is how linguistics should be interpreted. As a discipline that goes beyond the status of linguistics, linguistics is more accurately identified as the science of signs and symbols and the contexts that accompany them. Linguistics began to succeed in canceling the predicate given to laypeople, namely as a linguistic science. Linguistics can even be a solution for various other disciplines, including fiscal and monetary policy issues. Fiscal and monetary policies that require analysis of the past, present, and future phenomena can be answered immediately with a linguistic analysis knife. Critical discourse analysis is confidently presented as a solution to this problem. This is born from the perspective that policies are drawn up in language and Linguistics is considered the most effective and efficient tool for studying languages. Linguistics is empirically proven to be effective and efficient in answering various problems of civilization.

Fiscal and monetary policy is an important phenomenon that is directly proportional to the economic condition. If the policy made by the decision holder is not optimal, then the economic condition of a community is also not optimal. If the economic situation is not optimal, then the future of the community is also not optimal.

Considering that fiscal and monetary policies are crucial matters, every policy related to the economic existence of a community, country, or even a global area needs to be critically analyzed. This is necessary for the good of the policy itself and the stability of

Copyright: (C) 2021 the Author(s). This article is an open access article distributed under the terms and conditions of the Creative Commons Attribution (CC-BY) 4.0 license (https://creativecommons.org/licenses/by/4.0/). Published by Al-Kindi Centre for Research and Development, London, United Kingdom. 
a region's economy. Critical Discourse Analysis can be used as a theoretical basis and a method for critically analyzing economic policies. The policy in question is more focused on fiscal policy and monetary policy.

New research is worth doing if it touches at least one of these two traits: urgent and interesting. It would be better if a study had both properties. This study aims to provide a paradigm and confidence for every analyst, actor, and policyholder not to hesitate and make maximum use of Linguistic potential to achieve goals, goodness, and big missions in the fiscal and monetary fields. This research also tries to provide an essential reference for formulating strategies, tactics, and models of linguistic colored solutions to solve fiscal and monetary problems.

\section{Literature reviews}

The interactions between fiscal policy and monetary policy are a complex topic, as the role of each respective authority has a different impact on the economy. Therefore, the type of relationship established by both authorities is essential to determine how their policies will influence inflation, debt, and economic growth. When monetary policy dominates fiscal policy, the monetary authority permanently controls inflation, as it is free to set the base level for money. However, if fiscal policy dominates monetary policy, then the latter authority loses some influence in controlling inflation (Afonso, Alves, Bahote, 2019, p. 132-133). Konuki (2000) analyzes the impact of short-term fiscal and monetary policies on aggregate demand by using the IS-LM model-BOP with the structural analysis method of ECM.

In understanding a phenomenon, including fiscal and monetary phenomena, the ability to read signs and symbols from statements, policies, or ideas is the key to making accurate conclusions. The social situation and dynamics that affect and are affected by fiscal and monetary policies must be read correctly by stakeholders so that they are not mistaken in evaluating, anticipating, intervening, and making follow-up policies after that. Misreading the phenomenon is a setback and even a total misdirection in action, including formulating a policy. This is where linguistics plays a significant role. Linguistics can maximize its resources for reading and translating each text and context of a phenomenon into a valuable variable in observation, investigation, and research. (Siregar, 2020, p. 13-15).

\section{Research methods}

The method used in this research is interpretive holistic with a qualitative literal approach. The holistic interpretive method analyzes the text by relating it and its relevance to the context and then abstracting it into a complete picture. The qualitative paradigm aims to describe conditions and phenomena as they are. Denim said qualitative research contains an approach and interpretation of the natural meaning: "This means that qualitative researchers study things in their natural settings, trying to make sense of, or to interpret, phenomena in terms of the meanings people bring to them" (Denzyme et al. 2000, p. 4).

So, as a part of qualitative research, this research interprets the meaning of linguistic theory, especially critical discourse analysis, and then relates it to the business economic policy analysis method.

Concerning the study of literature, this paper bases its discussion on the literature that discusses theories of critical discourse analysis. The theory in question is non-economics theory. In other words, the research data in this paper is not based on a field research paradigm that takes data from the field. On the other hand, as already mentioned, this paper presents a literature review on critical discourse analysis theories and their possible applications in business economic policy analysis.

Furthermore, the method used to describe the discussion in this paper is a qualitative descriptive method. The discussion is presented using words and sentences, not using numbers. The discussion is theoretical by presenting concrete proposals related to the research title without testing theories and opinions. This is acceptable in qualitative research.

\section{Results and Discussion}

Business economic policies that are commonly analyzed are fiscal policy and monetary policy. A fiscal policy is a policy made by the government to direct a country's economy through government spending and income (in taxes).

Changes in the level and composition of taxes and government spending can affect the following variables: (1) Aggregate demand and the level of economic activity, (2) Patterns of distribution of resources, and (3) Distribution of income.

By implementing fiscal policy, the government seeks to influence the course of the economy. With fiscal policy, the government tries to direct the economy towards the desired state, such as intervening in the level of national income, affecting employment opportunities, stimulating national investment support, and affecting the distribution of national income. 
On the other hand, monetary policy is implemented to achieve internal balance (high economic growth, price stability, equitable development) and external balance (balance of payments balance) as well as achieving macroeconomic objectives, namely maintaining economic stability, which can be measured by employment opportunities, price stability and a balanced international balance of payments. If stability in economic activity is disturbed, monetary, fiscal policy can be used to restore it (stabilization action). The influence of monetary policy will first be felt by the banking sector, which will have a logical consequence on the real sector. This is where the discipline of linguistics, through critical discourse analysis, can act as a technology for analyzing phenomena and signs.

Critical discourse analysis is the development of Discourse Analysis theory. To understand this theory in-depth, the concept of discourse needs to be considered first. The term discourse comes from the Sanskrit wac/ wak/ vak, which means 'to say, 'to speak' (Mulyana, 2005, p. 15). In linguistic studies, the term discourse refers to a language unit that is larger than a sentence. Discourse is a complete construction in the linguistic habitat, the highest and largest grammatical unit that can be realized or realized in words, sentences, paragraphs, or a complete essay.

Linguists introduce the term discourse as a translation of the English word discourse. The word discourse comes from the Latin discursus, which means 'run to and fro,' 'run back and forth' or 'run from different directions' (cf. Mulyana, 2005, p. 4; Purwoko, 2007, p. 2). On the other hand, the word discourse in English is defined as "communication of words," "expression of ideas," "conversations," and "written treatises in the form of speeches, lectures and so on" (Bustan, 2010, p. 4). In terms of meaning, the term adopted by linguists supports the author's view of business economic policy as a discourse that must be analyzed.

Referring to the etymology, definitions, and various understandings, experts from different linguistic schools, developed which then formulated the concept of discourse differently. The concept of discourse is divided into two groups' views: the structuralist group and the post-structuralist group. The view of the structuralist group was coined by Ferdinand de Saussure (1857-1913). Based on the view of the structuralists, discourse is a tool to understand reality objectively.

In contrast to the views of structuralists, post-structuralists do not only see discourse as a tool to understand objective reality, but more than that, discourse is a tool to exercise control over specific purposes (Sim and Loon, 2008). The post-structuralist views are also used in this paper. Business economic policy is not just an ordinary discourse that must be studied but sees the policy itself as a tool to exercise control to support certain/hidden purposes.

As post-structuralist figures, Ernesto Laclau and Chantal Mouffe (1985) state that discourse constructs meaning in the social world and fundamentally states that language is unstable and meaning is never permanent. Laclau and Mouffe (1985) state that no discourse is a closed entity; on the contrary, discourse constantly undergoes transformations caused by relationships or interactions with other discourses. This theory gave birth to various concepts regarding discourse, among them the concept proposed by Crystal (1992, p. 25) as quoted below: "...discourse is a continuous stretch of (especially spoken) language larger than a sentence, often constituting a coherent unit such as a sermon, argument, joke, or narrative...".

The definition above understands that discourse is a continuous series of language more prominent than a sentence and is a coherent unit such as a sermon, argumentation, or narrative. So, the word discourse contains an expansive meaning in the scope of human life. This is in line with Van Dijk's opinion, which states that discourse is not only a sentence but an action (Titschaer et al., 2009, p. 43).

Discourse is also defined using ideology concerning social status, power, and identity (Fiona and Tim (2015, p. 119). This view is one of the views of post-structuralists who accept one of the scientific problems raised. On the other hand, Cook (1997, p. 6) argues that language- language in use, for communication - is called discourse. Based on this opinion, Cook (1997) then defines discourse as stretches of language perceived to be meaningful, unified, and purposive, which means discourse is a series of related sentences to form a harmonious meaning between the sentences. Thus, a series of sentences cannot be called discourse if there is no harmony of meaning.

On the other hand, a series of sentences form a discourse because a harmonious meaning is formed from the sequence. Cook (1997) wants to state that the meaning of discourse can change according to the socio-political and cultural context in which the discourse is born. The discourse in question contains the interests of certain groups and is used as an act to hegemony groups that are not in line with policymakers.

For clarity, the following three views on discourse analysis that have developed so far are presented. First, the positivism-empirical view perceives language as a tool that bridges humans and objects outside themselves. One of the characteristics of this view is 
the separation between thought and reality. According to this view, one does not need to know the objective meaning or values underlying a statement because the most important thing is whether a statement is correctly stated according to syntactic rules. Discourse analysis theory in this view only focuses on its analysis only grammatically. This is the first view of discourse analysis.

The second view is the view of constructivism which sees language as a tool to understand the objective reality that is separated from the subject as a messenger of language. In other words, this view rejects the view of empirical positivism. In the view of constructivism, language cannot be separated from the subject that produces it. The subject is a central factor in discursive activities and social relations (cf. Mulyana, 2005). Based on this view, discourse analysis only focuses on the subject concerning social relations.

The third view is the post-structuralist view, known as critical discourse analysis. Critical discourse analysis is a more progressive view of constructivism. Constructivism is considered less sensitive to producing and reproducing meaning that occurs historically and institutionally (cf. Lubis, 2014). Critical discourse analysis considers constructivism to have not been able to analyze the factors of power relations that are always inherent in every discourse, which plays a role in producing forms of discourse. Power relations, especially in the formation of subjects and various acts of representation in society, gave birth to a critical paradigm or critical discourse analysis (cf. Mulyana, 2005). In this paper, every existing business economic policy is considered closely related to power relations for the benefit of a group.

The language in business economic policy is understood as more than an extension of the subject. Discourse is the production and representation of broader power relations, political, social, cultural, or business economic power. The appearance of discourse to the public results from a strategy of a person or group of people who want to gain and/or perpetuate their power in society (Badara, 2012).

The keywords in critical discourse analysis are ideology, power, text production, discourse strategy, discourse battles, socio-cultural and political contexts, etc. These terms are the hallmark of Critical Discourse Analysis theory (cf. Coupland and Jaworski, 2001, pp. 145-148). In critical discourse analysis, people do not view discourse solely as a linguistic text but as a broader cultural text, a product that goes through a lengthy production process and is influenced by certain conditions, situations, ideologies, views, and powers (Latupeirissa, 2014). This research perspective sees fiscal and monetary policy as a discourse. Thus, this research can directly examine these policies using the critical discourse analysis method.

Several critical linguistic figures helped develop the theory of critical discourse analysis, namely: Foucault (1926-1984), Fowler (1985; 1986; 1996), Fairclough (1989, 1995, 2005, 2006), Kress (1985), Sykes (1985), Van Dijk (1985; 2001), West and Zimmerman (1985), Birch (1996), and Wodak (1996) (Santoso, 2009, p. 53). These figures are adherents of critical sciences who challenge the notion of structuralism (cf. Sim and Loon, 1998). In subsequent developments, Jørgensen et al. (2010, p. 115) stated that from various theoretical models,

In the critical discourse analysis developed by the figures above, two theories are most often used. These two theories represent other critical discourse analysis theories because they are the fastest-growing communication, culture, and society approaches. The two theories of critical discourse analysis are the theory developed by Van Dijk $(1985 ; 2001)$ and the theory developed by Fairclough (1989, 1995, 2005, 2006). On the other hand, (Adi 2011) states that of all the theories of AWK that have developed, only Van Dijk's theory of critical discourse analysis $(2001,2014)$ and Fairclough $(1989,1995,2005,2006)$ analyzes texts at the macro level.

Fairclough's theory of critical discourse analysis $(1989,1995,2005,2006)$ is used as a perspective in this study as a theory and method of business economic policy analysis. The selection of Fairclough's model of critical discourse analysis (1989, 1995, 2005, 2006) is based on two things; First, critical discourse analysis is the most popular method today. The following reason is that when compared to van Dijk's critical discourse analysis (2001, 2014), AWK Fairclough (1989, 1995, 2005, 2006) has advantages in analyzing discourse up to the stage of "social-cultural change in society." In this case, Fairclough's critical discourse analysis (sees the influence of the analyzed business economic policy concerning the socio-cultural changes of the society in which the policy is taken.

According to Fairclough, every discourse that appears in text, conversation, or anything else, is not seen as natural, natural, and neutral but is a form of struggle and struggle for power. Concerning this research, every business economic policy taken is a form of struggle and struggle. For this reason, these policies need to be critically analyzed. Furthermore, Fairclough (1995a) says that text is valued as a domain of representation and significance of the world and experience and is open to various interpretations. According to him, any trivial discourse is a form of power struggle. Thus, every discourse analysis is always associated with the dimensions of power (cf. Latupeirissa, 2014). 
Jørgensen et al. (2010) stated that the critical approach, according to Fairclough, has a theoretical basis in looking at the interrelationships between micro-events (verbal acts) and macro structures that condition and produce these micro-events. The critical approach rejects the clear line between micro and macro studies. With the dialectic between macro and micro in its study, critical discourse analysis can reveal the symptoms of naturalization of understanding and map the forms of social determination and the influence of discourse on participants.

Based on the opinions of experts as mentioned above, the analysis of business economic policies needs to underlie the concept of policy as a discourse that is not neutral. The policy is a hegemonic act carried out by the actors. The actors are the decisionmakers who formulate the policy in question. The purpose of the policies taken is to win the power struggle. Power struggles can occur directly or covertly.

Fairclough $(1989,1995,2005,2006)$ argues that there need to be three levels, or aspects of analysis, 6 . These three levels or aspects, in other terms, are referred to as three levels of analysis (cf. Latupeirissa et al.,2018, 2019a, 2019b: Latupeirissa, 2019). The three levels of analysis of the Fairclough model are theories that can also be used as critical discourse analysis methods. The first is the analysis of the next level, the second is the analysis of discursive practices concerning text production and consumption of texts, and the last is the analysis of socio-cultural practices.

Text analysis is done syntactically, paradigmatically, or a combination of both. Syntax analysis intends to look at the vocabulary used, see the semantic and sentence aspects. This analysis also emphasizes coherence and cohesiveness, how relations between words and sentences form particular meanings. The paradigmatic analysis is text analysis by paying attention to the symbols or signs used in the text to find the overall meaning (Jørgensen et al., 2010, p. 127). In this analysis, the business economic policies taken need to be scrutinized, especially regarding the vocabulary used, the sentence construction, and the hidden meanings behind the policy text. The construction of the language used needs to be seen carefully from various aspects.

Regarding the vocabulary used and the sentence construction used, a fiscal and monetary policy analyst needs to look at every sentence form that exists; For example, sentences in the policy tend to use active or passive sentences. If the passive voice is used more, there is a possibility that the policy is trying to hide or protect certain actors. On the other hand, if the active voice is used more, there is a possibility that the policy will be more hegemonic. Another example in this analysis is looking at the sentence's complexity, which will lead to ambiguity.

Concerning vocabulary, a critical policy analyst can use quantitative methods, namely by calculating particular vocabulary, which is semantically in the same field of meaning, which is more likely to be used in a policy. The dominant vocabulary is a vehicle for certain ideologies.

Next, by looking at the construction of the division of points/paragraphs/sub-chapters/chapters. A critical analyst can calculate when something is written in more points/paragraphs/sub-chapters/chapters with quantitative methods. For example, in fiscal and monetary policy "A," the topics "X" and "Y" are both discussed. However, after seeing it from the point of view of critical discourse analysis, it turns out that the topic "Y appears more in paragraph divisions. This can be interpreted as " $\mathrm{Y}$ is considered more important than "X." These are thoughts related to critical discourse analysis at the next level in a fiscal and monetary policy.

The points above are suggestions. These proposals can be selected based on field data. The core of the first-level analysis is a detailed analysis of the meaning of language, an analysis of the strengths and weaknesses of the language used in policy formulation, and an analysis of the interpretation of the policy language.

The second level of business economic policy analysis is the level of discursive practice. In analyzing the level of discursive practice, what is examined in Fairclough's critical discourse analysis $(1989,1995,2005,2006)$ is the process of production and consumption of texts. Fairclough (in Jørgensen et al., 2010) emphasizes the linkage of discursive practice with discursive and non-discourse conditions that affect the production of discourse or the construction of reality (discourse) by a social force. Analysis at this level is done by linking text and practice. The interpretation of the text or symptoms is followed by an interpretation of the form of discursive practice regarding what lies behind economic policy discourse.

A critical analyst needs to look at the policy's background or "why" factors in analyzing fiscal and monetary policy. This is called discursive practice analysis. Some of the questions that a critical analyst must ponder are:

1. "Why did this policy emerge," 
2. "Who made this policy,"

3. "What is the background of decision-makers,"

4. "How do people respond to this policy."

This analysis is carried out based on what has been mentioned previously: there is no neutral discourse content in the perspective of critical discourse analysis. In other words, there is no neutral business economic policy in practice. On the other hand, the critical discourse analysis paradigm views every business economic policy as a form of the power struggle that is never neutral.

The last is the third level of business economic policy analysis. The third level is socio-cultural practice. At this third level, there is a process of the existing discourse order and how social actors try to change or support the discourse order. This is based on the assumption that the social context outside the practice of discourse influences how discourse emerges and presents itself. Sociocultural practice is not directly related to the text but determines how the text is produced and understood through the mediation of discursive practice. The analysis carried out at this stage is referred to as explanation or social analysis, which consists of the situational level (specific social context when discourse appears), institutional (the influence of organizational institutions in the practice of discourse production), and the last is societal (macro aspects such as the political system). , the economic system or the cultural system of society as a whole that determines who is in power, what values are dominant and affect the discourse production process) (cf. Jørgensen et al., 2010, p. 131).

Pragmatically, the analysis at this last level looks at socio-cultural changes resulting from a business economic policy. First, analysts need to look at the initial situation before specific policies regarding the business economy are taken. Second, analysts need to look at the changing situation after the policy is taken. There are significant changes that have a positive impact on the people around them. This third business economic policy analysis is carried out through statistical tests or by distributing questionnaires and interviews.

Thus a business economic policy analyst needs to analyze business economic policy at three levels, namely (1) text level analysis, (2) discursive practice level analysis, and (3) socio-cultural practice level analysis. The three-level analysis as described above will undoubtedly produce a critical analysis of business economic policies, hoping that the policy itself will be better and that the economic output of business in the future will be of higher quality.

\section{Conclusions and Recommendations}

\subsection{Conclusion}

The Linguistic perspective through the critical discourse analysis method identifies fiscal and monetary policies as not neutral or subjective and partisan. The policies produced by decision-makers in a particular agency or country are acts of fighting as a hegemonic activity of a particular group. Some of these actions bring good for the economic development of an agency/country's business. On the other hand, some bring badness for certain institutions/countries. The role of linguistics through the critical discourse analysis method can actively function effectively and efficiently by reading these policies' points of view, semantic meaning, and pragmatism.

Not only that, but Linguistics through critical discourse analysis methods can also predict the domino effect, cause and effect, and the final reflection of the implementation of each of these policies. Also included in the role of Linguistics through critical discourse analysis methods is to design recommendations for the best steps in implementing fiscal and monetary policies.

In summary, it can be understood that Linguistics through the critical discourse analysis method plays a role in fiscal and monetary policy in 3 levels, namely:

1. The text level to see hidden meanings or intentions in the language used in the policy itself,

2. The level of discursive practice to see policy-making actors and certain policy situations or backgrounds are born, and

3. The level of socio-cultural practice to look at the results or significant changes resulting from the policy itself.

Thus, the final conclusion is that critical discourse analysis can play a role in 3 things related to fiscal and monetary policy, namely:

1. Analysis of text is an analysis of linguistic elements in sentence construction used in formulating policies,

2. Analysis of discourse practice is a background analysis behind the decision-makers who formulate policies and other situations and conditions behind the birth of business economic policies, and

3. Analysis of socio-cultural and political is an analysis that identifies the changes that occur due to these policies. 
Each of these levels will reach the point of maximum benefit if it is acculturated holistically and comprehensively in the process of data collection, analysis, and conclusion.

\subsection{Suggestions}

It is highly recommended that the holders of fiscal and monetary policy understand the conception of Linguistics, especially the method of critical discourse analysis. At the very least, ask for scientific views from those who understand the concept. This is very reasonable if we look at the breadth of the stimulator and segmentation variables that are affected by the fiscal and monetary policy decisions themselves.

Nevertheless, it is understandable the controversy and debate that arose over this research. For this reason, it is also highly recommended to immediately develop further research to formulate the most effective and efficient strategies, tactics, and models as a form of positive contribution to linguistics, especially critical discourse analysis methods to the world of economics, especially fiscal and monetary.

\section{References}

[1] António A, José A, \& Raquel B. (2019) Interactions between monetary and fiscal policies, Journal of Applied Economics, 22:1, 132151, DOI: $10.1080 / 15140326.2019 .1583309$

[2] Altavilla, C. (2003). Assessing monetary rules performance across EMU countries. International Journal of Finance and Economics, 8(2), 131151.

[3] Andrade, J. P., \& Pires, M. C. D. C. (2011). Implications of public debt indexation for monetary policy transmission. Journal of Applied Economics, 14(2), 257-268.

[4] Badara, A. (2012). Discourse Analysis. Theory, Method, and Its Application to Media Discourse. Jakarta: Kencana Prenada Media Group

[5] Bustan, F. (2010). Discourse Analysis. Kupang: Undana Press.

[6] Cook, G. (1997). Discourse Analysis. Oxford: Oxford University Press.

[7] Coupland, N. and Jaworsk, A. (2001). Discourse, in The Routledge Companion to Semiotics and Linguistics. London: Routledge

[8] Crystal, D. (1992). Introducing Linguistics. Harlow: Penguins.

[9] Denzin N. and Lincoln Y. (2000). Handbook of Qualitative Research. London: Sage Publications Inc.

[10] Fairclough, N. (1989). Language and Power. New York: Longman Group.

[11] Fairclough, N. (1995). Critical Discourse Analysis: The Critical Study of Language. London: Longman.

[12] Fairclough, N. (1995). Media Discourse. London: Edward Arnold.

[13] Fairclough, N. (2003). Analyzing Discourse Norman Fairclough: Textual Analysis for Social Research. London: Routledge

[14] Fairclough, N. (2005). Analyzing Discourse. Textual Analysis for Social Research. London: Routledge.

[15] Fairclough, N. (2006). Discourse and Social Change. Cambridge: Polity Press.

[16] Fiona, E. and Tim, M. (2015). Why Do Linguistics? India: Deanta Global Publishing Services

[17] Foucault, M. (1978). The History of Sexuality. New York: Pantheon.

[18] Favero, C. (2002). How do monetary and fiscal authorities behave? (CEPR, Discussion Paper No. 3426).

[19] Galí, J., \& Perotti, R. (2003). Fiscal policy and monetary integration in Europe. Economic Policy, 18(37), 533-572.

[20] Hurford J.R., Heasley B., Smith M. (2007). Semantics: A Coursebook. New York: Cambridge University Press.

[21] Jørgensen, M. and Phillips, L. J. (2002). Discourse Analysis as Theory and Method. London: SAGE Publications.

[22] Jørgensen, M. and Phillips, L. J. (2010). Discourse Analysis, Theory, and Methods. Yogyakarta: Student Library.

[23] Siregar, I. (2021). Verbal Communication of Schizophrenic Patients Due to Neurotransmitter Distortion.QALAMUNA: Jurnal Pendidikan, Sosial, Dan Agama,13(2), 543-556. https://doi.org/10.37680/qalamuna.v13i2.1037

[24] Siregar, I. (2020). Exploration and Implementation of the Cultural System as a Solution to National and State Problems. http://repository.unas.ac.id/id/eprint/811

[25] Siregar, I. (2021). Analysis of Betawi Language Interference on the Morphology of Adolescent Speech in Jakarta. Journal of Humanities and Social Sciences Studies, 3(8), 54-60. http://doi.org/10.32996/jhsss.2021.3.8.7

[26] Siregar, I. (2020). Geografi Leksikon Betawi. Jakarta: LPU Unas.

[27] Siregar, I. (2021). Epistemological Challenges Against Sociolinguistics. International Journal of Linguistics Studies, 1(2), 37-42. https://doi.org/10.32996/ijls.2021.1.2.6

[28] Siregar, I. (2021). The Existence of Culture in its Relevance to the Dynamics of Globalization: Bahasa Indonesia Case Study. International Journal of Cultural and Religious Studies, 1(1), 33-38. Retrieved from https://www.al-kindipublisher.com/index.php/ijcrs/article/view/2285

[29] Wolters, M. (2012). Estimating monetary policy reaction functions using quantile regressions. Journal of Macroeconomics, 34(2), 342-361. 